\title{
RNA Binding Proteins and its Regulation of Gene Expression
}

\author{
Kyung Hee Roh $\cdot$ Han-Chul Kang* · Jong-Bum Kim · Hyun-UK Kim • \\ Kyung-Ryeol Lee $\cdot$ Sun Hee Kim
}

\section{RNA 결합 단백질과 유전자 발현조절}

노경희 · 강한철* - 김종범 - 김현욱 - 이경렬 · 김순희

Received: 29 January 2015 / Accepted: 19 March 2015 / Published Online: 30 September 2015

(C) The Korean Society for Applied Biological Chemistry 2015

\begin{abstract}
The role of RNA-binding proteins (RBPs) to regulate expression of genes seems to be very important. RBPs play important roles in RNA related bioprocess such as transcription, pre-mRNA splicing, polyadenylation, transport, localization, translation, turn over and maintenance of structure. Despite of many researches on RNA binding proteins, detailed mechanisms of these proteins have not been fully understood. It seems that many parts of RBPs remains unknown and should be characterized for the better understanding of gene expression. Recently, genetic, biochemical, and bioinformatic analysis of genomes revealed a vast array of RBPs and many parts are interesting to understand bioprocessing including gene expression.
\end{abstract}

Keywords binding protein $\cdot$ RNA

\section{서 론}

RNA 결합 단백질(RNA-binding proteins; RBP)들은 세포내에서 단일 또는 이중 나선의 RNA와 결합하여 리보핵단백질

K. H. Roh $\cdot$ H.-C. Kang $\cdot$ J.-B. Kim $\cdot$ H.-U. Kim $\cdot$ K.-R. Lee $\cdot$ S. H. Kim Department of metabolic engineering, National Academy of Agricultural Science, Rural Development Administration, Jeonju-si Wansangu Nongsaengmyeongro 370, Jeollabukdo 560-500, Republic of Korea

*Corresponding author (H.-C. Kang; hckang09@korea.kr)

This is an Open Access article distributed under the terms of the Creative Commons Attribution Non-Commercial License (http://creativecommons. org/licenses/by-nc/3.0/) which permits unrestricted non-commercial use, distribution, and reproduction in any medium, provided the original work is properly cited. (ribonucleoprotein) 복합체 형성에 관여하는 단백질들이다. RBPs 들은 여러 종류의 구조 모티프를 가지고 있는데 이들은 RNA 인식 모티프(RRM), dsRNA 결합 부위 및 zinc finger 등이다. 효모의 경우 전체 유전자의 5-8\% 가량이 RNA 결합 단백질로 추정되고 있다. C.elegans와 D.melanogaster의 경우는 전체 유 전자의 $2 \%$ 가량이 RNA 결합 단백질로 추정되고 있다(Lasko, 2000; Keene, 2001).

대부분의 성숙된 $\mathrm{mRNA}$ 는 핵에서 세포질로 빨리 이동하기 때문에 핵에 남아 있는 대부분의 RNA 결합 단백질들은 pre$\mathrm{mRNA}$ 들과 결합된 이종 리보핵단백질(hnRNPs)들이다. 일반적 으로 생물체들이 진화하면서 인트론의 숫자와 더불어 RNA 결 합 단백질들도 급속히 증대되고 있다. 전핵생물에서는 전사와 번역이 대체로 하나의 작용처럼 일어나지만, 진핵세포에서는 이 들 두 가지 작용이 핵과 세포질로 나뉘어서 작용한다. 이러한 작용은 진핵생물의 유전자 조절에 있어서 전사후 조절이 상당 히 복잡하게 일어나게 할 수 있도록 해주는 것이다. 전핵 및 진 핵세포의 유전자 발현 조절 관련 연구에 있어서 전반적으로 유 전자들의 전사(transcription)에 대한 연구가 전사후 조절(posttranscrip-tional regulation)보다 상대적으로 많이 연구가 되어 왔 다. RNA 결합 단백질들은 RNA 들의 전사후 조절에 있어서 아주 중요한 역할을 한다. 전사후 조절은 유전자의 splicing, polyadenylation, RNA 안정화, 및 RNA 분해 등 여러 종류의 RNA 대사에 있어서 서로 다른 단계에서 작용을 한다(Keene와 Tenenbaum, 2002; Hieronymus와 Silver, 2004; Moore, 2005; Keene, 2007; Halbeisen 등, 2008).

일반적으로 RNA 결합 단백질들은 전사후 조절을 위하여 mRNA의 5'UTR 또는 3'UTR 부위에 일반적으로 위치하고 있 는 조절 부위와 결합을 한다. 거의 모든 RNA결합 단백질들이 $\mathrm{RNA}$ 에 결합하지만 이들 결합은 RNA 서열 등에 따라 결합하 게 되는 데 이들 결합을 위해서는 RNA 결합부위가 중요한 역 할을 하게 되며 대부분 보조 모티프를 갖추고 있다. 이들 RNA 결합 단백질들은 보조 모티프를 통하여 다른 단백질들과도 서 
로 상호작용을 하기도 하는 데 상당 부분은 전사후 조절에 관 계된다. 결론적으로 세포들은 각각의 mRNA에 따라 구성과 배 열이 서로 다른 리보핵 단백질들을 수없이 생합성하게 된다. 이 들 리보핵단백질들은 mRNA가 기능을 수행 하게 되는 과정에 서 더욱 변성을 하게 된다. 한편 RNA 결합 단백질 들은 $\mathrm{mRNA}$ 이외에도 다른 종류의 RNA에도 결합하여 작용을 하게 된다(Matera 등, 2007). 최근의 이러한 추세에 맞추어 RNA 결 합 단백질들을 확인하고 특성을 연구하기 위한 방법 들이 개발 되고 있다. 이종 리보핵단백질들과 mRNP 복합체들은 RNA 단 백질 복합체 들의 ultraviolet (UV)를 사용한 고정화(crosslinking) 방법에 의해서 분리되기도 한다(Niranjanakumari 등, 2002). 이러한 방법들은 세포들을 용해시키는 과정에서 발생할 수 있는 각종 비특이적인 RNA-단백질 관계들을 배제시킬 수 있는 등의 장점 때문에 RNA-단백질 관계를 효과적으로 연구하 기 위한 좋은 방법으로 알려지고 있다(Mili와 Steitz, 2004).

따라서 본 논문에서는 이러한 연구 추세에 따라 최근에 이루 어지고 있는 각종 RNA 결합 단백질 및 이와 관련된 각종 역 할 등에 대하여 정리하여 보았다.

\section{RNA 결합 부위}

최근에 Bobak 등의 보고(2015)에 따르면 인체의 뇌, 가슴, 허 파 및 신장 등 16 종류의 기관별로 나누어 RNA 결합 단백질을 분석한 결과 이들 조직에서 RNA 결합 단백질들은 RNA 와 관 련이 없는 단백질들에 비해서 훨씬 높은 발현량을 나타내고 있 다. 따라서 이러한 고발현은 RNA 결합 단백질들의 생체내에서 의 생리, 생화학 기작에 매우 중요하게 작용함을 시사하는 것 이다. 또한 8종류의 암세포에 관련하여 RNA 결합 단백질을 분 석한 결과 대부분의 암세포에서 이들 단백질들의 발현이 음의 상관관계 즉, 정상적으로 건강한 세포에 비해 발현량이 부족한 경우가 보고되고 있다(Bobak 등, 2015). 이렇게 발현되는 RNA 결합 단백질들은 하나 또는 그 이상의 RNA 결합부위를 갖추 고 있다. 지금까지 잘 알려진 RNA 결합부위로는 다음과 같이 알려지고 있다. K-homology $(\mathrm{KH})$ domain (Type 1 and $\mathrm{II}$ ), RGG (Arg-Gly-Gly) box, Sm domain, DEAD/DEAH box, Zinc finger (ZnF, 대부분 C-x8-X-x5-X-x3-H), 이중나선 RNA
결합부위 (dsRBD), cold-shock domain, pumilio/FBF (PUF 또 는 PUM-HD) domain, Piwi/Argonaute/Zwille (PAZ) domain 등이 알려지고 있다(Chen과 Varani, 2005; Lunde 등, 2007).

RNA 결합 단백질들은 하나 또는 여러 개의 RNA 결합부위 또는 기타 보조적인 부위들을 가지고 있는 복잡한 구조이다 (Lunde 등, 2007). 이러한 특성 때문에 RNA 결합 단백질들은 같은 단백질 내에서도 RNA 에 대한 결합을 포함하여 여러 가 지 기능을 하도록 해준다. 특성 연구가 잘 된 RNA 결합부위들 은 하나의 단백질 내에 종종 다수의 반복되는 구조가 나타나는 데 이러한 예로는 polypyrimidine tract-binding protein (PTB/ hnRNP I), poly(A) 결합단백질(PABP), U2AF65 및 U1A 등이 있다(Lunde 등, 2007). 일반적으로 하나의 RNA 결합부위는 보 통 2-6개 가량의 핵산과 결합하는데 이러한 결합부위 여러 개 가 존재하여 보다 크거나 복잡한 RNA 들과 결합할 수 있게 하고 따라서 RNA 결합 특이성 또는 친화력 등을 높이게 된다 (Maris 등, 2005). 이러한 예로서 PUF 단백질들을 들 수 가 있 는데 이들은 8 개의 Puf RNA 결합 반복서열을 갖추고 있으며 이들 각각은 약 40 개의 아미노산으로 구성되어 $\alpha$ 형 나선구조 를 이룬다(Edwards 등, 2001; Wang 등, 2002). 인체 pumilio 단백질의 RNA 결합 관련 구조를 보면 8개의 반복서열의 제 각 각은 목표 RNA 에 있어서 하나의 핵산을 인식하여 결국 8 개 의 핵산과 결합하게 된다(Wang 등, 2002). 이와 같이 특이적이 며 고도의 친화성 결합 때문에 PUF-RNA 관계를 예측하게 하 고 단백질 결합에 유효하게 응용할 수 있게 한다(Wang 등, 2002; Opperman 등, 2005; Cheong 과 Hall, 2006). Table 1 은 각종 RNA 결합 단백질과 이들의 결합 부위, 구조 인식 DNA 또는 RNA 등을 정리한 것이다.

최근에는 RNA 결합 단백질의 결합 부위를 보다 정확히 밝 혀내기 위해서 PAR-CLIP (Photoactivatable Ribonucleoside Enhanced Crosslinking and Immunopre cipitation) 방법이 개발되었다 (Spitzer 등, 2014). 이 방법에서는 RNA 와 단백질의 결합에 대한 crosslinking 방법을 기존의 방법보다 개량한 것이 주요 내 용이다. 이를 위해서 4-thiouridine 또는 4-thioguanosine 등의 핵산 유도체를 세포에 투여한 다음 $365 \mathrm{~nm}$ 를 투여하여 보다 강 력하게 crosslinking이 일어나게 되며 살아있는 세포에서는 훨씬 효과적이다.

Table 1 RNA binding domain and its structure and nucleic acids recognized

\begin{tabular}{|c|c|c|c|}
\hline RBPs and binding domain & Structure of the domain & RNA or DNA recognized & References \\
\hline hnRNP A1, RBM3, PTB, HuD; RRM & $\begin{array}{l}\beta \alpha \beta \beta \alpha \beta \text { barrel like with RNP1 and } \\
\text { RNP2 motifs }\end{array}$ & ssRNA, ssDNA & Chaudhury et al. (2010) \\
\hline Dicer; PAZ & B-barrel reminiscent OB-fold & dsRNA & Park et al. (2011) \\
\hline Argonaute; PIWI & $\begin{array}{l}\text { RNase H core; five-stranded } \beta \text {-sheet and } \\
\alpha \text {-helices }\end{array}$ & dsRNA & Meister (2013) \\
\hline Tat, hnRNPA1, YB-1; Arginine rich & Glycine/aromatic residue-rich domains & ssRNA, dsRNA & Chaudhury et al. (2010) \\
\hline TFIIIA, Tra-1, WT1; Zinc finger & $\beta \beta \alpha$ structure & dsRNA & Carroll (2011) \\
\hline UNR, CspB, YB-1; CSD (cold-shock domain) & $\beta$-barrel structure & ssRNA, ssDNA & Brown and Jackson (2004) \\
\hline hnRNP K, FMR 1; KH (K-homology) & $3 \beta$-sheet and $\alpha$-helices & ssRNA, ssDNA & Bomsztyk et al. (2004) \\
\hline \multicolumn{2}{|c|}{ PKR, Stufen, RNAseIII Dicer, ADAR1; dsRBD $\alpha \beta \beta \beta \alpha$ fold } & dsRNA & Legendre et al. (2013) \\
\hline elF4A, DHH1; RNA helicase & Domain 1 and 2 & dsRNA & Shen et al. (2009) \\
\hline
\end{tabular}




\section{전사 및 번역후 변이}

Polyadenylation은 mRNA의 핵막 통과, 번역효율 및 mRNA의 안정화 등에 상당히 중요한 역할을 한다. 이들 polyadenylation 과 관련된 기능을 수행하는 데에도 여러 종류의 RNA 결합 단 백질들이 관여한다. 히스톤 $\mathrm{mRNA}$ 를 제외하고 거의 대부분의 진핵세포 mRNAs 들은 $3^{\prime} \operatorname{poly}(\mathrm{A})$ 를 갖추게 되는데 이 과정에 서 중요하게 작용하는 단백질이 $\mathrm{CPSF}$ 이다. $\mathrm{CPSF}$ 는 3' 말단 서 열에 poly(A) 결합단백질 등과 같이 결합하여 poly(A) polymerase 등의 활성을 증대시킨다. Poly(A) polymerase 그 자체로서는 효 소활성이 무기력하나 이들 단백질 들과 결합할 때 그 활성을 나타낸다(Glisovic 등, 2008). 이는 적어도 4개의 polypeptide 로 구성되어 있고 AAUAAA 서열에 결합하는 데 이중에서 $\mathrm{CPSF}-160$ 과 CPSF-30이 RNA 결합에 중요하게 작용하는 부위 로 생각되고 있다(Ryan 등, 2004). CPSF의 경우에도 그 자체 로는 효소 활성을 나타내지 않으나 poly(A) 결합 단백질 (PABPN1)과 상호작용을 할 경우 $\operatorname{poly}(\mathrm{A})$ polymerase의 활성을 촉진시킨다(Bienroth 등, 1991). PABN1이 poly(A) 꼬리와 상호 반응하기 위해서는 RNA 결합 부위와 arginine이 밀집된 Cterminal domain이 필요하다(Wahle 등, 1999). PABPN1은 번역 후에 아르기닌 메틸화의 과정을 거치는데 메틸화가 않된 $\mathrm{PABPN} 1$ 은 메틸화가된 PABPN1 보다 올리고머 형태가 쉽게 된 다(Perreault 등, 2007). 이러한 사실들은 $\mathrm{OPMD}$ 에서 메틸화가 핵응집 정도에 영향을 미침을 시사하는 것이다.

최근에는 RNA의 안정성에 영향을 미치는 것으로 알려지고 있는 N6 methyladenosine 메칠화와 관련되는 RNA 결합 단백 질, 예를 들어 methyl transferase (METTL3, 14) 및 demethylase 들이 보고되고 있다. 기존의 DNA 관련 demethylase와 달리 최 근에 알려진 $\mathrm{ALKBH} 5$ 같은 경우는 RNA에 특이적으로 작용하 는 일종의 m6A demethylase로 알려지고 있다(Zheng 등, 2013). $\mathrm{ALKBH} 5$ 는 in vivo와 in vitro 모두에서 mRNA의 $\mathrm{m} 6 \mathrm{~A}$ 를 탈 메칠화시켜 본래의 $\mathrm{mRNA}$ 로 환원시키는 기능을 보이고 있다. $\mathrm{ALKBH} 5$ 를 돌연변이시킨 실험용 쥐의 경우 $\mathrm{mRNA}$ 에서 $\mathrm{m} 6 \mathrm{~A}$ 의 량이 증대되고 있으며 자가사멸세포에 영향을 미치고 수정 능력이 손상되는 결과를 가져왔다(Zheng 등, 2013). mRNA의 염기서열중 아데노신의 N6methyl-adenosine으로의 변화는 동물 줄기세포의 분화를 조절하는데 아주 결정적인 역할을 하는 것 으로 최근에 알려지고 있다(Bouxan 등, 2015). mRNA의 메칠 화와 관련하여 전사체들의 잔존량을 분석한 결과 $\mathrm{mRNA}$ 의 일 부 염기서열이 메칠화된 결과 mRNA의 수명(half-life)이 보다 짧아지는 것으로 밝혀지고 있으며 세포에서 차지하는 비중도 줄 어들고 있다. 따라서 METTL3의 제거는 이미 발현된 유전자의 양을 늘리게 되는 결과를 가져오고 있다(Bouxan 등, 2015).

RNA 결합 단백질들의 번역후 변이는 또 다른 특징을 보여 주고 있는데 이로 인하여 RNA 결합 특성, 기능 및 리보핵단백 질의 위치정립(localization) 등에 대한 변화를 야기시킨다. 지금 까지 알려지고 있는 중요한 RNA 결합 단백질 변화들은 인산 화(phosphorylation), 아르기닌 메틸화(arginine methylation) 및 소형의 유비퀴틴 유사체 변화(Small Ubiquitin related Modification) 등이다. $\alpha \mathrm{CP}-1$ 및 $\alpha \mathrm{CP}-2$ 의 인산화는 그들의 poly $(\mathrm{rC})$ 결합작 용을 감소 시킨다(Leffers 등, 1995). 성장촉진 인자(growth factor) 및 산화 스트레쓰 등은 이종 리보핵단백질 $\mathrm{K}$ 의 인산화 상태를 바꿀 수 있다(Ostrowski 등, 1991; Schullery 등, 1999). S.cerevisiae에서 Hrp1과 Yral (Aly/REF)들의 두 종류의 RNA

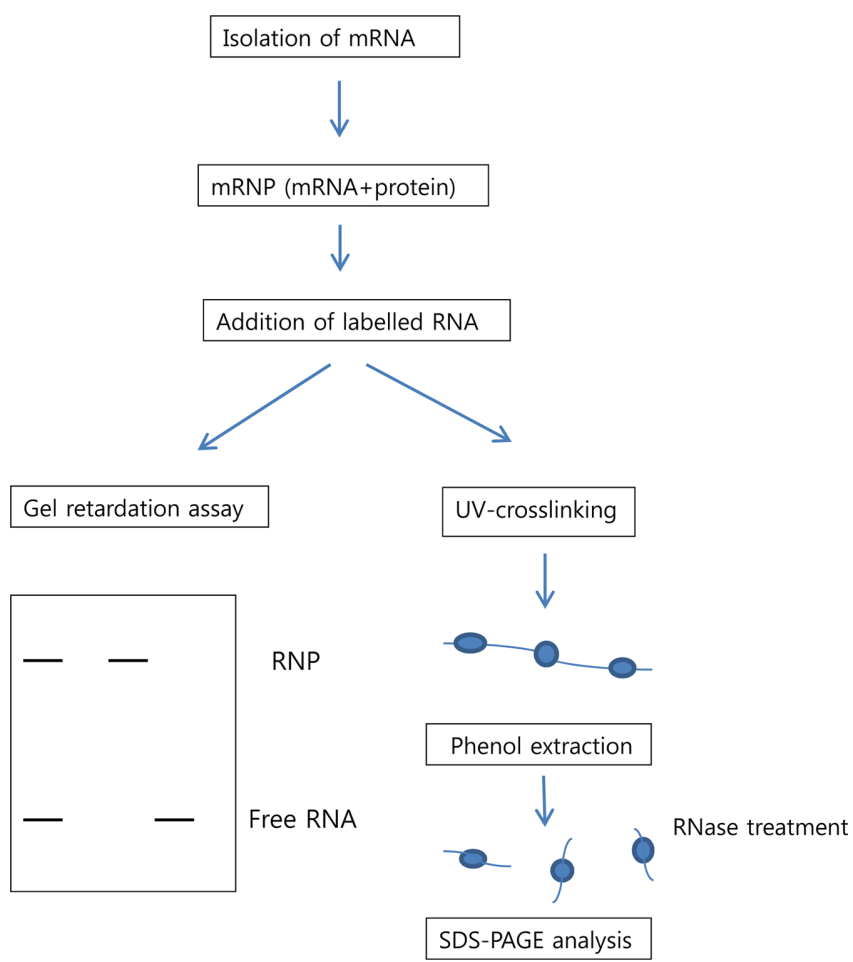

Fig. 1 Cross-linking of RNA-protein complexes and isolation of RBPs. mRNA or total RNA can be isolated, then, UV cross-linking can be performed. Alternatively, UV cross-linking can be carried out before isolating RNA-protein complexes. Formaldehyde can be also used to fix protein and RNA.

결합 단백질들이 mRNA processing 및 수송에 관여하는 것으 로 알려지고 있는데 이들은 arginine methyltransferase 및 $\mathrm{Hmt1}$ 등에 의해 메틸화가 이루어진다(Shen 등, 1998; Yu 등, 2004). 이러한 메틸화작용은 Hrp1과 Yra1을 함유하는 리보핵단 백질의 형성에 작용할 수 있다. 이종리보핵단백질 $\mathrm{C}$ 와 $\mathrm{M}$ 의 $\mathrm{SUMO}$ 화는 이들 리보핵단백질들의 구조적 변화를 야기시키고 핵과 세포질간의 이동을 조절하게 된다(Hou 등, 2002).

RNA 편집(editing)은 가장 많이 일어나는 RNA 변이중의 하 나인데 이는 아데닌(A)에서 이노신(I)으로의 교체 등이 하나의 예이다. 이렇게 아데닌에서 이노신으로 변하는 전사후 변이가 일어나면 RNA의 핵산함량이 변하게 되는데 이러한 반응은 $\mathrm{ADAR}$ 단백질에 의해 촉진된다(Valente 등, 2005). 가장 잘 알 려진 RNA 편집 관련 단백질중 하나는 $\mathrm{ADAR}$ 단백질이다. 이 는 RNA의 핵산을 변경시킴으로서 $\mathrm{mRNA}$ 의 전사후 변경에 관 여하는 단백질이다. 이는 $\mathrm{ADAR}$ 에 의한 효소반응으로 아데닌 을 이노신으로 바꾸어 작용하여 결국 유전자의 다양성을 높이 는 역할을 하게 된다. RNA 편집의 대다수는 non-coding RNA 부위에서 발생하지만 일부는 단백질 코딩 RNA 전사체에서도 발생하는 것으로 알려지고 있다(Glisovic 등, 2008). 또한 이런 반응에 의해서 RNA 염기 서열도 변하기 때문에 유전자 산물 이 다양하게 변할 수 있다. 대부분의 RNA 편집은 non-coding 유전자 부위에서 발생하는데 일부의 유전자는 coding 서열 에 서 발생하기도 한다(Nishikura 등, 2006). ADAR이 관여하게 되 는 pre-mRNA 기질은 종종 불완전한 duplex RNA인데 이는 편집이 이루어질 아데닌을 갖는 exon과 intronic non-coding 부 
위 사이의 염기쌍형성에 의해 이루어진다(Higuchi 등, 1993). 아 데닌/이노신 편집의 전형적인 예는 glutamate receptor GluR-B $\mathrm{mRNA}$ 인데 편집 부위의 글루타메이트가 아르기닌으로 변한다. 현재까지 알려지고 있는 대부분의 아데닌/이노신 변이는 ion channels coding에 관여하는 신경세포, G-protein 과 수용체 및 글루타메이트와 세로토닌 수용체 들과 관련되는 전사체들에서 일어나고 있다(Hoopengardner 등, 2003). 한편 RNA와 단백질 과의 관계는 RNA 결합 단백질들을 직접 분리하여 분석하는 것 이 가장 좋으며 Fig. 1은 RNA와 단백질의 결합을 고정시켜 RNA 결합 단백질들을 분리하는 최근의 추세를 정리한 것이다.

\section{mRNA export}

일단 pre-mRNA가 형성되어 번역할 준비가 된 mRNA, 즉 전 사, splicing 및 3' 말단 processing 등이 완료된 mRNA는 핵에 서 세포질로 이동을 한다. 이러한 mRNA의 이동과정에서도 RNA 결합 단백질들은 중요한 역할을 한다. 이러한 과정에서도 RNA 결합 단백질들은 핵공을 거쳐 mRNA를 전달할 수 있도 록 운반용 복합 단백질체를 형성하는 과정을 거치며 최종적으 로 세포질에서 목적 $\mathrm{mRNA}$ 를 전달하고 재순환하는 과정을 거 치게 된다. TAP는 constitutive transport element (CTE)에 결 합하는 것으로 알려졌다. 이러한 CTE 는 retroviral 전사체의 수 송에 필요한 것으로 알려졌는데 이는 후에 mRNA 의 수송에 도 필요한 것으로 알려졌다(Ernst 등, 1997; Gruter 등, 1998). AP/NXF:p15 heterodimer는 mRNA 수송에 있어서 중요한 역할 을 담당한다. Xenopus 난모세포에서 TAP를 과발현시키면 전사 체의 수송이 촉진되며 그 반대의 경우에는 수송이 잘 이루어지 지 않아 이들이 $\mathrm{mRNA}$ 의 수송을 직접 담당한다는 사실을 알 수 있다. 한편 TAP와 $\mathrm{p} 15$ 는 RNA에 대하여 낮은 친화력을 보 이기 때문에 이들이 상호 작용하기 위해서는 또 다른 단백질 들이 필요하다(Santos-Rosa 등, 1998; Katahira 등, 1999). Aly/
$\mathrm{REF}$ 단백질은 $\mathrm{TAP}$ 와 직접 작용하는데 이들은 $\mathrm{mRNA}$ 에 $\mathrm{TAP}$ 를 모으는 역할을 한다(Stutz 등, 2000; Taniguchi와 Ohno, 2008).

\section{이중 나선의 RNA에 결합하는 단백질}

이중 나선의 RNAs 들도 여러가지 기능을 수행하는 경우가 많 다(Table 2). 이들은 역시 각종 이중나선 RNA 결합 단백질 (dsRBPs)들과 상호작용을 하는데 이들 대부분은 dsRNA-binding motif (dsRBM)라고 불리는 부분을 가지고 있다. 이들은 대략 70 개의 아미노산 서열부위를 갖추고 부분적으로 이중나선으로 형성된 dsRNA 와 상호 반응하는데 어떤 경우는 특정서열을 인 식하지 않는 상태로 RNA-DNA hybrids와 반응하기도 한다. 이 들 dsRNA 결합단백질들은 단백질-단백질 상호작용을 통하여 결합하기도 한다. 여러 종류의 생물체에 존재하는 $\mathrm{dsRBMs}$ 들의 구조는 핵자기공명(NMR) 또는 X-ray 결정학 등의 방법으로 연 구되어 왔다. NMR 방법에 의하여 E.coli의 RNase III, Drosophila melanogaster의 staufen 5 , 및 인체 $\mathrm{PKR}$ 의 dsRBM 등이 밝혀 졌고 이들 모티프들은 $\alpha$-helix 구조를 이루는 특징을 보이고 있 다(Kharrat 등, 1995; Nanduri 등, 1998). 이중나선 RNA 결합 단백질들 중에서 interleukin enhancer-binding 요인 3와 nuclear factor 90 (NF90)들은 각종 세포에 많이 존재하는 이중나선 RNA 결합 단백질들의 예인데 이들은 Ilf3의 splicing에 의해 각 각 생성된다. 이들은 공통의 $\mathrm{N}$-말단 및 중심 서열을 갖추고 있 지만 $\mathrm{C}$-말단은 각각 특이한 서열을 갖추고 있다. 이들은 전사 후 및 번역후의 변화에 의하여 상당히 많은 부분이 이질적으로 변하게 되어 세포내 위치 및 기능 등이 서로 다르게 작용한다. 비록 Ilf3 및 NF90이 유전자 발현의 촉진인자로 처음에 알려졌 지만 이들은 이외에도 cell cycle 및 효소활성의 조절 등 보다 넓은 범위로도 작용한다는 사실 등이 알려졌다(Patino 등, 2014). Fig. 2는 각종 RNA 결합 단백질과 이들이 내포하는 각종 효소 및 $\mathrm{dsRBD}$ 등을 정리하여 모식도로 나타낸 것이다.

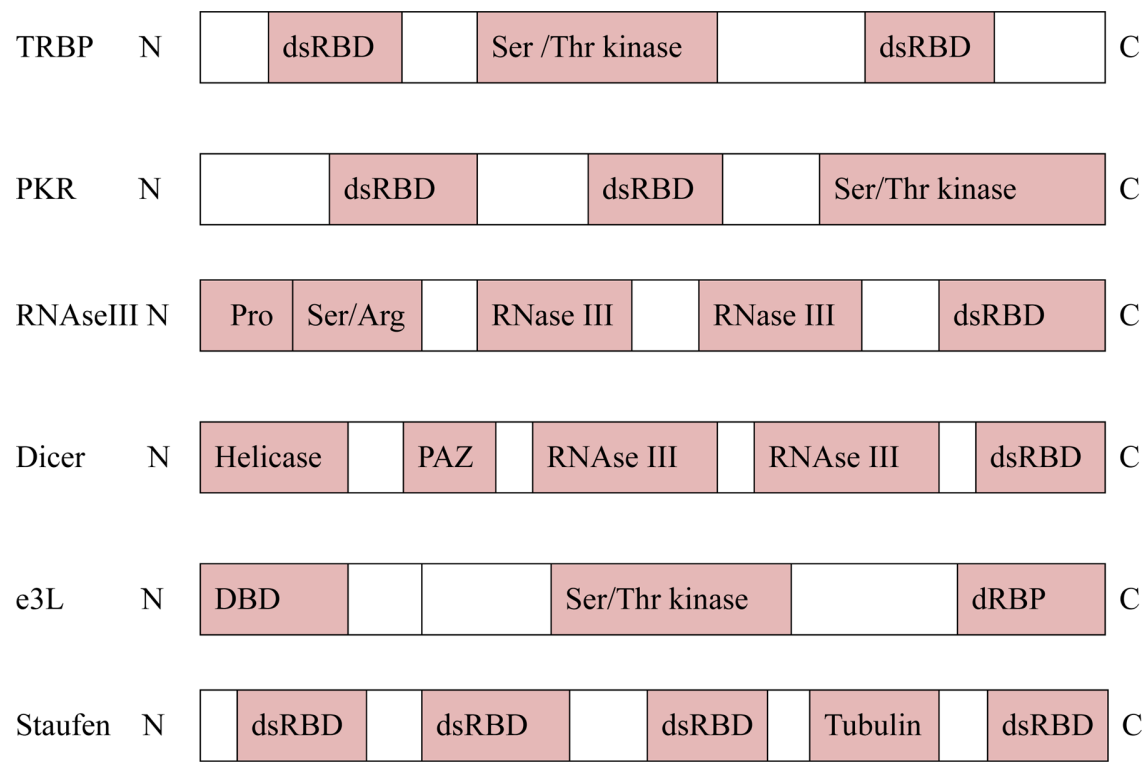

Fig. 2 Modular structure of various dsRNA-binding proteins. DBD, DNA binding domain; dsRBD, double strand RNA binding domain; N, Nterminal; C, C-terminal. 
Table 2 Double-stranded RNA-binding proteins and its functions

\begin{tabular}{|c|c|c|}
\hline dsRBP & Functions & References \\
\hline PKR & Ser/Thr kinase, phosphorylation of elf2a, IFN-induced antiviral response, apoptosis & Cruz-herrera et al. (2014) \\
\hline TRBP & PKR activator (PACT), PKR inhibitor (TRBP), Ribosomal and hnRNA association (Xlrbpa) & Redfern et al. (2013) \\
\hline E3L & Viral PKR inhibitor & Thakur et al. (2013) \\
\hline RHA & RNA/DNA helicase, transcriptional coactivator (RHA), dosage compensation (MLE) & Narva et al. (2012) \\
\hline NF90 & NFAT transcription factor, PKR activator, mitosis phosphorylation (MPP4), & Patino et al. (2014) \\
\hline Stufen & mRNA localization & Legendre et al. (2013) \\
\hline RNase III & dsRNA specific endoribonuclease & Kharrat et al. (1995) \\
\hline
\end{tabular}

$\mathrm{dsRBM}$ 은 넓게 분포하고 있는 구조이며 다양한 종류의 기능 을 수행하고 있다. 이는 특정 RNA 의 인식에도 사용되며(예, Staufen), 효소활성에도 필수적으로 사용되기도 한다(예, ADAR). 이들 dsRBM은 또한 dsRBP의 기능상태를 조절할 수도 있고(예, $\mathrm{PKR}$ ) 또는 다른 dsRBP 를 조절하기도 한다(예, E3L). 따라서 이들 $\mathrm{dsRBM}$ 이 단백질내에 존재할 경우 RNA 결합 단백질들 과의 상호작용이 존재할 것으로 추정할 수가 있다. dsRBM은 RNA processing, RNA 위치정립, RNA 저해(interference), RNA 편집 및 번역 억제 등에서 중요한 역할을 수행한다. dsRBMs 들은 $\alpha$-helix와 $\beta-1 \beta-2$ loop를 경유하여 RNA duplex와 상호 반응을 한다. Fig. 2은 다양한 종류의 dsRBP에 있어서 DNA 및 RNA 등과의 결합 부위 등과 관련되는 구조적 모식도이다.

\section{선택적 splicing}

전사체의 splicing은 하나의 유전자를 이용하여 여러 종류의 단 백질을 번역할 수 있도록 하는 체계이며 따라서 이러한 작용은 전사후 조절이 단백질 발현에 있어서 더욱 복잡하게 만드는 요 인이다(Blencowe, 2006). 일반적으로 고등 생물에서는 선택적 splicing이 상당히 활발히 일어나고 있다. 이러한 현상 때문에 더 많은 종류의 단백질들을 만들어 낼 수가 있는데 RNA 결합 단백질들이 이러한 작용에서도 관여를 한다. 예를 들면 신경세 포에 특이적인 RNA 결합 단백질인 NOVA의 경우는 RNA 에 있는 특이 서열(YCAY; Y는 피리미딘, 즉 $\mathrm{U}$ 또는 $\mathrm{C}$ )을 인식하 고 결합함으로서 hnRNA에 대해 선택적 splicing을 한다 (Dreyfuss 등 2002; Glisovic 등, 2008). 이들 단백질들은 splicing 관련 단백질들을 재결집시키는데 예를 들면 SR 단백질들은 snRNPs 들(예; U1 snRNP, U2AF snRNP 등)의 재결집을 통하여 splicing 역할에 중요하게 관여한다. 또한 RNA 결합 단백질들은 splicesome 그 자체의 구성성분이기도 하다. 결국 splicesome은 snRNA와 단백질들이 복합체를 이루어 인트론을 제거하는 역할 을 한다(Matera 등, 2007).

인트론이 아주 적은 생물체의 하나인 Saccharomyces cerevisiae 의 경우만 보더라도 splicing 은 유전자 조절에 상당히 기여를 하고 있다(Pleiss 등, 2007). 많은 종류의 RNA 결합 단백질들, 예를 들면 $\mathrm{hnRNP}$ 라든가 serine/arginine-rich (SR) 단백질들은 많은 종류의 RNAs들에 결합하여 다양한 기능을 수행한다. 그 런데 hnRNPA1 단백질은 exonic splicing silencer 염기서열에 결합하고 SR splicing 요인 들을 억제시켜 splicing 을 조절 하 기도 하며(Vassileva와 Matunis, 2004) telomere 말단부위와 작 용하여 telomerase 활성을 촉진하기도 한다(Zhang 등, 2006). 한편 $\mathrm{hnRNP} \mathrm{A} 1$ 은 인체의 pri-mir $18 \mathrm{a}$, 즉, miR-18a의 전구체
와 결합하여 Drosha-mediated processing 을 촉진하는 것으로 알려져 결국은 RNA 결합 단백질이 miRNA 의 성숙에도 관여 하는 것으로 알려졌다 (Guil과 Caceres, 2007).

\section{mRNA의 위치 정립}

전사후 조절의 한 예로서 $\mathrm{mRNA}$ 의 위치 정립을 들 수 있는데 Drosophila 배아의 경우 대략 $70 \%$ 가량의 mRNA들이 고유의 세포기관내 위치정립 특성을 보이고 있다(Lecuyer 등, 2007). $\mathrm{mRNA}$ 의 위치 정립은 단백질 발현이 특정 부위에서 발현되도 록 하는 데 중요하다. 이러한 작용은 특히 생물체들의 초기 발 생에 중요하다. 이러한 과정에서 RNA 결합 단백질들이 작용하 여 특정부분에서 단백질이 생성될 수 있도록 중요한 역할을 수 행한다. 이러한 과정을 수행하는 단백질중의 하나가 ZBP1인데 이는 전사가 일어나는 부위의 $\beta$-actin mRNA와 결합하여 $\mathrm{mRNA}$ 가 세포질로 이동하게 한다. RNA 위치 정립에 관여하는 RNA 결합 단백질의 또 다른 예로는 FMRP가 있는데 이는 일 부 neuronal dendrites에서의 denfritic mRNA의 위치 정립에 관여한다(Dictenberg 등, 2008). ZBP1은 $\beta$-actin mRNA의 위치 정립에서의 역할과 더불어 번역 시작을 억제함으로서 $\beta$-actin $\mathrm{mRNA}$ 의 번역을 억제하는 데에도 관여한다. 리보좀이 적당히 결합하여 번역이 시작되도록 $\mathrm{ZBP} 1$ 은 $\mathrm{mRNA}$ 에서 제거되어야 한다.

\section{RNA 결합 활성도 및 RNA 서열의 인식}

RNA 결합 단백질들은 목적 RNA와 결합하는 과정에 있어서 $\mathrm{RNA}$ 의 서열 뿐만 아니라 3차원 구조까지 인식하여 결합하기 때문에 상당히 특이적으로 결합하게 된다(Stefl 등, 2005). 이러 한 관계는 일부의 RNA 결합 단백질들이 전사의 단계에서부터 $\mathrm{RNA}$ 에 계속 결합하여 분해될 때 까지 결합된 상태로 있는가 하면 일부의 RNA 결합 단백질들은 RNA 에 잠시 동안만 결 합하여 RNA 의 splicing 및 이동 등의 작용에 관여하기도 한 다 (Bandziulis 등, 1989).

RNA 인식부위(recognition motif)는 일반적으로 4줄의 $\beta$-구조 ( $\beta$-sheet)와 두개의 $\alpha$-나선 ( $\alpha$-helix) 를 지니는 75-85개의 아미 노산으로 이루어진 작은 단백질이다. 이러한 RNA 인식부위의 구조에 따라 이들은 RNA-단백질 관계뿐 아니라 RNA-RNA 및 단백질-단백질 관계까지도 인식하도록 해준다. 4 줄의 $\beta$-평면은 $\mathrm{RNA}$ 와 작용하는 것으로 알려지고 있는데 보통 이들은 2-3개 의 뉴클레오타이드와 결합하는 것으로 알려지고 있다. 또한 강 
Table 3 RRM domains and its relation with RRM-containing RBP and target sequences (For review; Auweter et al., 2006; Daubner et al., 2013).

\begin{tabular}{ccc}
\hline RRM-domain & Binding sequences & $\begin{array}{c}\text { RRM-containing } \\
\text { RBPs (examples) }\end{array}$ \\
\hline RRM1 & UUUUUUU & Sex-lethal (Sxl) \\
& UAGG & hnRNP A1 \\
& AAAA & PABP \\
& UUAUUU & HuD \\
RRM2 & UCNU & PTB \\
& UGU & Sex-lethal (Sxl) \\
& UUAGG & hnRNP A1 \\
& AAAA & PABP \\
& UU & HuD \\
& CNUNN & PTB \\
RPM3 & UAU & PTB \\
& UCNU & PTB \\
\hline
\end{tabular}

력한 결합과 특이성은 RNA 인식부위들 내부끼리의 상호 작용 또는 RNA 인식부위들 사이의 관계 들에 의하여 더욱 촉진 된 다. 이러한 특성으로 인하여 RNA 인식부위가 아주 많으며 생 물학적으로 중요한 역할을 하는 것이 설명된다(Bandziulis 등, 1989). Table 3은 RNA 결합 단백질들과 결합하는 RNA 인식 부위 및 염기서열 등을 정리한 것이며 Table 4는 RNA 결합 단백질과 관계되는 $\mathrm{RNA}$ 들의 구조와 관계를 정리한 것이다.

RNA 단백질 응집체(RNP aggregates)들은 보통 퇴행성질환체 내에서 종종 형성이 되고 있다. 그런데 이러한 RNA 단백질 응 집체들은 전사후 조절에 해롭게 작용할 수가 있다. 따라서 이 렇게 핵 또는 세포질의 RNA 단백질 응집체들의 축적에 의해 서 병이 촉진될 수 있다는 사실이 알려지고 있다(Mani 등 2013). 이러한 응집체들의 형성은 현재까지는 RNA 결합 단백 질들의 변이가 중요 원인으로 추측되고 있다. RNA 결합 단백 질의 응집체 형성과 관련하여 발생하는 질병으로는 Huntington's 병(Htt 변이), prion 병(Prp 변이), 알츠하이머(sporadic 형태 변 이) 등이 현재까지 알려지고 있다. 응집체 형성은 아니지만 RNA 결합 단백질의 변이에 의해서도 질병이 발생하며 현재까 지 spinocerebellar ataxias (SCA1-3,6,7,17, RNA 결합단백질에
있어서 glutamine의 증대), $\mathrm{SCA}-8$ (CUG 증대), $\mathrm{SCA} 10$ (AUUCU의 증대), $\mathrm{ALS}(\mathrm{b})$ (과립체형성), $\mathrm{ALS}$ (c) (RNA 변이), DM 1 및 2 (RNA 변이), FXTAS (RNA 변이), laminopathies (RNA 과립체형성), oculopharyngeal muscular dystrophy (알라 닌 증대) 및 Welander (RNA 과립체 형성) distal myopathy 및 distal myopathy 등이 RNA 결합 단백질의 이상과 관련되는 것으로 알려지고 있다(Review; Mani R 등 2013). 이와 같이 RNA 결합 단백질의 변이 또는 응집체 형성에 의해 수많은 질 병이 발생하는 바와 같이 RNA 결합 단백질은 RNA 를 통한 단백질 발현 조절에 매우 중요하게 작용하고 있다는 사실을 알 수 있다.

\section{RNA 결합 단백질 연구의 전망}

RNA 결합 단백질은 세포내에서 RNA와 결합하여 단백질의 발 현조절에 아주 중요하게 작용하는 것으로 최근에 알려지고 있 다. 이들 RNA 결합 단백질들의 유전자조절에 있어서의 전사후 조절, 각종 변이에 의한 결합 능력의 변화 등으로 인하여 이들 은 각종 질환의 원인이 되고 있다. 또한 RNA 결합 단백질들의 특성을 연구함으로써 동 식물체의 질환연구 및 유전자 개발 등 에 도움이 될 수 있다. 예를 들면 RNA와 단백질의 응집체 형 성과정을 분석하고 또한 해로운 응집체를 제거하는 기술을 개 발함으로써 각종 질환에 대한 예방 및 치료가 가능할 것으로 기대되고 있다. 더욱이 최근에 개발이 되고 있는 PAR-CLIP 등 의 방법에 의해서 RNA와 단백질과의 결합체 연구가 가속화되 고 있다. 한편 암세포의 경우에서도 RNA 결합 단백질의 발현 량이 비정상적으로 나타나고 있다. 따라서 RNA 결합 단백질을 이용하여 암세포 치료 연구에도 응용이 가능할 것으로 기대되 고 있다.

RNA 결합 단백질중에서는 RNA의 메칠화를 조절하여 줄기 세포의 분화를 조절하는 단백질이 알려지고 있다. 따라서 줄기 세포관련 RNA 결합단백질을 이용하여 이러한 줄기세포의 분 열능력을 조절하여 질병치료에 활용할 수 있을 것으로 기대가 된다. 예를 들어 RNA 결합 단백질의 일종인 METTL3를 줄여 줌으로서 특정 단백질 발현 관련 $\mathrm{mRNA}$ 의 량을 늘려주는 것 이 가능하다. 또한 최근에는 이러한 연구를 보조하기 위하여

Table 4 Structures of RNA substrates in complex with RNA

\begin{tabular}{|c|c|c|c|c|}
\hline Protein & Analytical method & RNA substrate & PDB & References \\
\hline Staufen & NMR & Single hairpin & IEKZ & Ramos et al. (2000) \\
\hline \multirow[t]{2}{*}{ TRBP/PACT } & X-ray & Coaxially stacked duplexes & IDI 2 & Ramos et al. (2000) \\
\hline & X-ray & Coaxially stacked duplexes & $3 \mathrm{ADL}$ & Yang et al. (2010) \\
\hline \multirow[t]{3}{*}{ ADAR } & NMR & Single hairpin & $2 \mathrm{~L} 3 \mathrm{C}$ & Stefl et al. (2010) \\
\hline & NMR & Single hairpin & $2 \mathrm{~L} 2 \mathrm{~K}$ & Stefl et al. (2010) \\
\hline & NMR & Single Hairpin & 2L3J & Stefl et al. (2010) \\
\hline \multirow[t]{2}{*}{ HYL 1/HEN 1} & X-ray & Coaxially stacked duplexes & 3ADL & Yang et al. (2010) \\
\hline & X-ray & Coaxially stacked duplexes & 3HTX & Huang et al. (2009) \\
\hline \multirow[t]{5}{*}{ RNAse III } & X-ray & Coaxially stacked duplexes & IRC7 & Blaszczyk et al. (2004) \\
\hline & X-ray & Coaxially stacked duplexes & IYZ9 & Gan et al. (2006) \\
\hline & X-ray & Coaxially stacked duplexes & IYYW & Gan et al. (2006) \\
\hline & X-ray & Coaxially stacked duplexes & $2 \mathrm{EZ6}$ & Gan et al. (2006) \\
\hline & NMR & Single hairpin & IT4L & Wang et al. (2001) \\
\hline
\end{tabular}

Note; PDB, protein data bank. 
RNA 결합 단백질의 지도까지도 상당히 진척이 되고 있다 (Inbal 등, 2014).

\section{초 록}

RNA 결합 단백질들이 유전자 조절의 다양한 범위에 작용한다는 사실이 아주 중요하다. 유전자의 전사에 관련된 유전자 조절이 많 이 연구가 되었어도 RNA 의 조절에 관한 연구는 상대적으로 부 진한 편이다. RNA 결합 단백질들은 RNA 와 관련되는 각종 과 정, 예를 들면 전사, pre-mRNA splicing, polyadenylation, 수송, 위치화, 번역, 분해 및 구조의 유지 등 다양한 범위에서 작용을 하고 있다. RNA 결합 단백질들의 많은 부분들이 아직 잘 알려 지지 않고 있으며 유전자 발현에 대해 더 잘 이해하기 위해 이 러한 부분의 연구가 더 수행되어야 한다. 최근에 유전학, 생화 학, 및 유전자들의 생물정보학의 발달 등으로 인하여 . RNA 결 합 단백질들의 다양한 분야들이 알려지고 있으며 이러한 부분 들이 많은 관심을 받고 있다.

\section{Keywords 유전자 조절· RNA · RNA 결합단백질}

감사의 글 본 연구는 Agricultural Science and Technology Development (프로젝트번호 PJ0100752015, 국립농업과학원, 농촌진흥청) 의 지원에 의하 여 수행된 과제이다.

\section{References}

Auweter S, Oberstrass FC, and Allain FH (2006) Sequence-specific binding of single-stranded RNA: is there a code for recognition? Nucleic Acids Res 34, 4943-59.

Bandziulis RJ, Swanson MS, and Dreyfuss G (1989) RNA-binding proteins as developmental regulators. Genes Dev 3, 431-7.

Bienroth S, Wahle E, Suter-Crazzolara C, and Keller W (1991) Purification of the cleavage and poly-adenylation factor involved in the 3'-processing of messenger RNA precursors. $J$ Biol Chem 266, 19768-76.

Blaszczyk J, Gan J, Tropea JE, Court DL, Waugh DS, and Ji X (2004) Noncatalytic assembly of ribonuclease III with doublestranded RNA. Structure 12, 457-66.

Blencowe BJ (2006) Alternative splicing: new insights from global analyses. Cell 126, 37-47.

Bomsztyk K, Denisenko O, and Ostrowski J (2004) One protein multiple process. Bioessays 26, 629-38.

Brown EC and Jackson RJ (2004) All five cold-shock domains of unr (upstream of $\mathrm{N}$-ras) are required for stimulation of human rhinovirus RNA translation. J Gen Virol 85, 2279-87.

Carroll D (2011) Genome engineering with zinc-finger nucleases. Genetics 188, 773-82.

Chaudhury A, Chander P, and Howe P (2010) Heterogeneous nuclear ribonucleoproteins in cellular processes. RNA 16, 1449-62.

Chen Y and Varani G (2005) Protein families and RNA recognition. FEBS J 272, 2088-97.

Cheong CG and Hall TM (2006) Engineering RNA sequence specificity of Pumilio repeats. Proc Natl Acad Sci USA 103, 13635-9.

Cruz-herrera C, Campagna M, Garcia M, and Villar L (2014) Activation of the double stranded RNA-dependent protein kinase PKR by sumo. J Biol Chem 29, 1-19.

Daubner G, Clery A, and Allan F (2013) RRM-RNA recognition; NMR or crystallography. Curr Opi Struc Biol 23, 100-8.

Dictenberg, Jason B, Swanger SA, Antar LN, Singer RH, and Bassel GJ (2008) A direct role for FMRP in activity-dependent dendritic mRNA transport links filopodial-spine morphogenesis to fragile $\mathrm{X}$ syndrome. Dev Cell 14, 926-39.

Dreyfuss G, Kim VN, and Kataoka N (2002) Messenger-RNA-binding proteins and the messages they carry. Nature Reviews Mol Cell Biol 3, 195-205.

Edwards TA, Pyle SE, Wharton RP, and Aggarwal AK (2001) Structure of Pumilio reveals similarity between RNA and peptide binding motifs. Cell 105, 281-9.

Ernst RK, Bray M, Rekosh D, and Hammarskjold ML (1997) A structured retroviral RNA element that mediates nucleocytoplasmic export of intron-containing RNA. Mol Cell Biol 17, 135-44.

Gan J, Tropea JE, Austin BP, Court DL, Waugh DS, and Ji X (2006) Structural insight into the mechanism of double-stranded RNA processing by ribonuclease III. Cell 124, 355-66.

Glisovic T, Bachorik JL, Yong J, and Dreyfuss G (2008) RNA-binding proteins and post-transcriptional gene regulation. FEBS Lett 582, 197786.

Gruter P, Carlos T, and Cayetato K (1998) TAP, the human homolog of Mex67p, mediates CTE-dependent RNA export from the nucleus. $\mathrm{Mol}$ Cell 1, 649-59.

Guil S and Caceres JF (2007) The multifunctional RNA-binding protein hnRNP A1 is required for processing of miR-18a. Nat Struct Mol Biol 14, 591-6.

Halbeisen RE, Galgano A, Scherrer T, and Gerber AP (2008) Posttranscriptional gene regulation: from genome-wide studies to principles. Cell Mol Life Sci 65, 798-813.

Hieronymus H and Silver PA (2004) A systematic view of mRNP biology. Genes Dev 18, 2845-60.

Higuchi M, Single FN, Kohler M, Sommer B, Sprengel R, and Seeburg PH (1993) RNA editing of AMPA receptor subunit GluR-B: a base-paired intron-exon structure determines position and efficiency. Cell 75, 136170.

Hoopengardner B, Bhalla T, Staber C, and Reenan R (2003) Nervous system targets of RNA editing identified by comparative genomics. Science 301, 832-6.

Hou VC, Komili S, and Casolari JM (2002) Decrease in hnRNP A/B expression during erythropoiesis mediates a pre-mRNA splicing switch. EMBO J 21, 6195-204.

Huang Y, Ji L, Huang Q, Vassylyev DG, Chen X, and Ma J-B (2009) Structural insights into mechanisms of the small RNA methyltransferase HEN1. Nature 461, 823-7.

Inbal P, Idit K, Manuel A, and Melissa C (2014) RBPmap: a web server for mapping binding sites of RNA-binding proteins. Nucleic Acids Res 14, $1-7$.

Katahira J, Strasser K, Podtelejnikov A, Mann M, and Jung JU (1999) The Mex67p-mediated nuclear mRNA export pathway is conserved from yeast to human. EMBO J 18, 2593-609.

Keene JD (2001) Ribonucleoprotein infrastructure regulating the flow of genetic information between the genome and the proteome. Proc Natl Acad Sci USA 98, 7018-24.

Keene JD (2007) RNA regulons: coordination of post-transcriptional events. Nat Rev Genet 8, 533-43.

Keene JD and Tenenbaum SA (2002) Eukaryotic mRNPs may represent posttranscriptional operons. Mol Cell 9, 1161-7.

Kharrat A, Macias MJ, and Gibson TJ (1995) Structure of the dsRNA binding domain of E. coli RNase III. EMBO J 14, 3572-84.

Lasko P (2000) The drosophila melanogaster genome: translation factors and RNA binding proteins. J Cell Biol 150, 51-6.

Lecuyer E, Yoshida H, Parthasarathy N, Alm C, and Babak T (2007) Global analysis of mRNA localization reveals a prominent role in organizing cellular architecture and function. Cell 131, 174-87.

Leffers H, Dejgaard K, and Celis JE (1995) Characterisation of two major cellular poly(rC)-binding human proteins, each containing three $\mathrm{K}$ homologous (KH) domains. Eur J Biochem 230, 447-53.

Legendre JB, Campbell ZT, and Conner P (2013) RNA targets and specificity of Staufen, a double-stranded RNA-binding protein in Caenorhabditis elegans. J Biol Chem 288, 2532-45.

Lunde BM, Moore C, and Varani G (2007) RNA-binding proteins: modular 
design for efficient function. Nat Rev Mol Cell Biol 8, 479-90.

Maris C, Dominguez C, and Allain FH (2005) The RNA recognition motif, a plastic RNA-binding platform to regulate post-transcriptional gene expression. FEBS J 272, 2118-31.

Matera AG, Terns RM, and Terns MP (2007) Non-coding RNAs: lessons from the small nuclear and small nucleolar RNAs. Nat Rev Mol Cell Biol 8, 209-20.

Meister G (2013) Argonaute proteins ; functional insight and emerging roles. Nature Rev Gen 14, 447-59.

Mili S and Steitz JA (2004) Evidence for reassociation of RNA-binding proteins after cell lysis: implications for the interpretation of immunoprecipitation analyses. RNA 10, 1692-4.

Moore MJ (2005) From birth to death; the complex lives of eukaryotic mRNAs. Science 309, 1514-8.

Nanduri S, Carpick B, and Yang Y (1998) Structure of the doublestranded RNA-binding domain of the protein kinase PKR reveals the molecular basis of its dsRNA-mediated activation. EMBO J 17, 5458-65.

Narva E, Rankonen E, Emani MR, and Lund R (2012) RNA-binding protein L1TD1 interacts with LIN28 via RNA and is required for human embryonic stem cell self-renewal and cancer cell proliferation. Stem cell 30, 452-60.

Niranjanakumari S, Lasda E, and Brazas R (2002) Reversible cross-linking combined with immunoprecipitation to study RNA-protein interactions in vivo. Methods 26, 182-90.

Nishikura K (2006) Editor meets silencer: crosstalk between RNA editing and RNA interference. Nat Rev Mol Cell Biol 7, 919-31.

Opperman L, Hook B, DeFino M, Bernstein DS, and Wickens M (2005) A single spacer nucleotide determines the specificities of two mRNA regulatory proteins. Nat Struct Mol Biol 12, 945-51.

Ostrowski J, Sims JE, Sibley CH, Valentine MA, and Dower SK (1991) A serine/threonine kinase activity is closely associated with a $65-\mathrm{kDa}$ phosphoprotein specifically recognized by the kappa B enhancer element. J Biol Chem 266, 12722-33.

Park JE, Heo I, Tian Y, and Simanshu D, and Kim VN (2011) Dicer recognizes the $5^{\prime}$ end of RNA for efficient RNA processing. Nature $\mathbf{4 7 5}$, 201-5

Patino C, Haenni AL, and Urcucqui S (2014) NF90 isoforms, a new family of cellular proteins involved in viral replication? Biochimie 4, 20-4.

Perreault A, Lemieux C, and Bachand F (2007) Regulation of the nuclear poly(A)-binding protein by arginine methylation in fission yeast. $J$ Biol Chem 282, 7552-62.

Pleiss JA, Whitworth GB, Bergkessel M, and Guthrie C (2007) Rapid, transcript specific changes in splicing in response to environmental stress. Mol Cell 2, 928-37.

Ramos A, Grunert S, Adams J, Micklem DR, and Proctor MR (2000) RNA recognition by a Staufen double-stranded RNA-binding domain. EMBO $J$ 19, 997-1009.

Redfern AD, Colley SM, and Beveridge DJ (2013) RNA-induced silencing complex (RISC) Proteins PACT, TRBP, and Dicer are SRA binding nuclear receptor coregulators. Proc Natl Acad Sci USA 16, 6536-41.
Ryan K, Calvo O, and Manley JL (2004) Evidence that polyadenylation factor CPSF-73 is the mRNA 3' processing endonuclease. RNA 10, 565-73.

Santos-Rosa H, Moreno H, Simos G, Segref A, Fahrenkrog B, and Pante N (1998) Nuclear mRNA export requires complex formation between Mex67p and Mtr2p at the nuclear pores. Mol Cell Biol 8, 6826-38.

Schullery DS, Ostrowski J, Denisenko ON, Stempka L, Shnyreva M, and Suzuki H (1999) Regulated interaction of protein kinase Cdelta with the heterogeneous nuclear ribonucleoprotein $\mathrm{K}$ protein. $J$ Biol Chem 274, 15101-9.

Shen EC, Henry MF, Weiss VH, Valentini SR, and Silver PA (1998) Arginine methylation facilitates the nuclear export of hnRNP proteins. Genes Dev 12, 679-91.

Shen R, Weng C, Yu J, and Xie T (2009) elF4a controls germline stem cell self-renewal by directly binding BAM function in the Drosophila ovary. Proc Natl Acad Sci USA 106, 11623-8.

Stefl R, Oberstrass FC, Hood JL, Jourdan M, Zimmermann M, and Skrisovska L (2010) The solution structure of the ADAR2 dsRBMRNA complex reveals a sequence-specific readout of the minor groove. Cell 143, 225-37.

Stefl R, Skrisovska L, and Allain F (2005) RNA sequence and shape dependent recognition by proteins in the ribonucleoprotein particle. EMBO Reports 6, 33-8.

Stutz F, Bachi A, Doerks T, Braun IC, Seraphin B, and Wilm M (2000) REF, an evolutionary conserved family of hnRNP-like proteins, interacts with TAP/Mex67p and participates in mRNA nuclear export. RNA 6, 638-50.

Taniguchi I and Ohno M (2008) ATP-dependent recruitment of export factor Aly/REF onto intronless mRNAs by RNA helicase UAP56. Mol Cell Biol 28, 601-8.

Thakur M, Seo EJ, and Dever TE (2013) Variola virus E3L Za domain but not its Z-DNA binding activity is required for PKR inhibition. RNA 23, $1-14$.

Valente L and Nishikura K (2005) ADAR gene family and A-to-I RNA editing: diverse roles in posttranscriptional gene regulation. Prog Nucleic Acid Res Mol Biol 79, 299-38.

Vassileva MT and Matunis MJ (2004) SUMO modification of heterogeneous nuclear ribonucleo-proteins. $\mathrm{Mol}$ Cell Biol 24, 3623-32.

Wahle E and Ruegsegger U (1999) 3'-End processing of pre-mRNA in eukaryotes. FEMS Microbiol Rev 23, 277-95.

Wang X, McLachlan J, Zamore PD, and Hall TM (2002) Modular recognition of RNA by a human pum-iliohomology domain. Cell 110, 501-12.

Wang X, Zamore PD, and Hall TM (2001) Crystal structure of a Pumilio homology domain. Mol Cell 7, 855-65.

Yang SW, Chen H-Y, Yang J, Machida S, Chua N-H, and Yuan YA (2010) Structure of Arabidopsis HYPONASTICLEAVES1 and its molecular implications for miRNA processing. Structure 18, 594-605.

Yu MC, Bachand F, McBride AE, Komili S, and Casolari JM (2004) Arginine methyltransferase affects interactions and recruitment of mRNA processing and export factors. Genes Dev 18, 2024-35.

Zhang QS, Manche L, Xu RM, and Krainer AR (2006) hnRNP Al associates with telomere ends and stimulates telomerase activity. $R N A$ 12, 1116-28. 